\title{
Aktivitas NADP(H) Oksidoreduktase pada Kultur Sel Kina (Cinchona ledgeriana Moens) Terelisitasi
}

\section{(The Activity of NADP(H) Oxidoreductase of Elicitated Cell Culture of Cinchona ledgeriana Moens)}

\author{
Maulidiyah Utami ${ }^{1}$, Diah Ratnadewi ${ }^{2 \star}$, Dyah Iswantini ${ }^{3}$, Trivadila $^{3}$
}

(Diterima September 2019/Disetujui Juni 2020)

\begin{abstract}
ABSTRAK
Tanaman kina (Cinchona ledgeriana Moens) merupakan tanaman industri penghasil metabolit alkaloid kuinolina. Untuk mempertahankan dan meningkatkan produksi kuinolina, khususnya kuinina, sistem kultur in vitro melalui metode kultur sel dapat menjadi alternatif yang baik. Apabila penggunaan elisitor dapat meningkatkan produksi suatu metabolit sekunder maka aktivitas enzim-enzim pada lintasan biosintesis metabolit sekunder tersebut diduga juga meningkat. Penelitian ini bertujuan untuk menguji aktivitas NADP(H) oksidoreduktase pada kultur sel kina yang dielisitasi dan mengevaluasi keterkaitan antara aktivitas enzim tersebut dengan produksi kuinina. Kultur sel kina dielisitasi menggunakan asam absisat (ABA) atau paklobutrazol (PBZ) yang dikombinasikan dengan sukrosa, sorbitol, atau manitol pada media woody plant (WP), di atas shaker selama 7 pekan. Konsentrasi kuinina ditentukan dengan kromatografi cair kinerja tinggi (HPLC) dan aktivitas enzim diukur menggunakan fluorometri. Hasil penelitian menunjukkan bahwa aktivitas enzim tertinggi terdapat pada perlakuan P7M (PBZ $7 \mathrm{mg} / \mathrm{L}+$ manitol 5,3 $\mathrm{g} / \mathrm{L}+\mathrm{sukrosa}$ $20 \mathrm{~g} / \mathrm{L}$ ), yang diikuti oleh perlakuan A3S (ABA $3 \mathrm{mg} / \mathrm{L}$ + sorbitol 5,3 g/L + sukrosa $20 \mathrm{~g} / \mathrm{L}$ ). Hasil ini sejalan dengan kadar kuinina yang dihasilkan. Aktivitas enzim terendah terdapat pada kultur tanpa elisitor (kontrol). Peningkatan aktivitas enzim pada perlakuan P7M dan A3S masing-masing sebesar 13,5 dan 8,5\% dibandingkan dengan sel kontrol.
\end{abstract}

Kata kunci: alkaloid kuinolina, elisitasi, fluorometri, NADP(H) oksidoreduktase

\section{ABSTRACT}

Cinchona ledgeriana Moens is an industrial plant producing secondary metabolite quinoline alkaloids. To maintain and moreover, to increase the quinoline production especially quinine, in vitro culture system through cell culture could be a potential alternative. If the use of elicitor in cell culture can increase the production of a secondary metabolite, the activity of the enzymes involved in the biosynthetic pathway of the secondary metabolite in question might be increasing. This study aimed to examine the activity of NADPH oxidoreductase in the elicitated cell culture of $C$. ledgeriana and to evaluate the correlation between the activity of this enzyme and the level of quinine production. The cell cultures of Cinchona were treated with abscisic acid (ABA) or paclobutrazol (PBZ), combined with sucrose, sorbitol, or mannitol in Wood Plant (WP) media, for 7 weeks on a shaker. The quinine concentration was determined using high-performance liquid chromatography (HPLC) and the enzyme activity was measured using fluorometry. The results showed that the highest enzyme activity was found in the P7M cells (PBZ $7 \mathrm{mg} / \mathrm{L}+\mathrm{mannitol}$ $5.3 \mathrm{~g} / \mathrm{L}$ + sucrose $20 \mathrm{~g} / \mathrm{L}$ ), followed by the A3S cells (ABA $3 \mathrm{mg} / \mathrm{L}$ + sorbitol $5.3 \mathrm{~g} / \mathrm{L}$ + sucrose $20 \mathrm{~g} / \mathrm{L}$ ). These results correspond to their production level of the quinine alkaloids. The lowest enzyme activity was found in the cultures without elicitor. The increase of $\mathrm{NADP}(\mathrm{H})$ enzyme activity in the P7M and A3S treatments were 13.5 and $8.5 \%$, respectively, compared to that in the control cells.

Keywords: elicitation, fluorometry, NADP(H) oxidoreductase, quinoline alkaloid

\section{PENDAHULUAN}

Kuinolina merupakan alkaloid yang berasal dari tanaman kina, termasuk Cinchona ledgeriana Moens. Alkaloid ini tergolong ke dalam kelas terpenoid indol.

\footnotetext{
${ }^{1}$ Sekolah Pascasarjana, Fakultas Matematika dan IImu Pengetahuan Alam, Institut Pertanian Bogor, Kampus IPB Dramaga, Bogor 16680

2 Departemen Biologi, Fakultas Matematika dan IImu Pengetahuan Alam, Institut Pertanian Bogor, Kampus IPB Dramaga, Bogor 16680

${ }^{3}$ Departemen Kimia, Fakultas Matematika dan IImu Pengetahuan Alam, Institut Pertanian Bogor, Kampus IPB Dramaga, Bogor 16680

*Penulis Korespondensi: Email: dratnadewi@apps.ipb.ac.id
}

Kuinolina spesifik, yaitu kuinina, sangat bermanfaat dalam berbagai bidang. Kuinina bermanfaat dalam bidang farmasi untuk mencegah dan mengobati penyakit malaria dan dalam bidang kedokteran digunakan sebagai marker untuk melihat efek obat terapeutik (de Pablos-Martinez et al. 2016). Kuinina juga dapat dipakai sebagai sumber antioksidan (Krishnaveni et al. 2015) dan digunakan sebagai pengaya cita rasa dalam produk minuman ringan (Awasthi et al. 2011; Flieger \& Zelazko 2015). Berbagai potensi yang dimiliki kuinina menjadikan alkaloid ini perlu dikaji lebih lanjut untuk mempertahankan, bahkan meningkatkan produksinya. Beberapa kendala dalam upaya mempertahankan produksi kuinina di antaranya ialah keterbatasan lahan 
tanam, proses alih fungsi lahan yang cepat, waktu panen yang lama, dan waktu pemulihan tanaman yang lama setelah dipanen. Oleh karena itu, peningkatan produksi kuinina dengan sistem kultur in vitro berpotensi menjadi alternatif yang baik, terutama melalui metode kultur sel. Peningkatan produksi kuinina dengan metode kultur sel tergolong efisien, baik dari segi bahan baku maupun waktu. Kultur sel juga menguntungkan karena populasi sel relatif homogen, yang memungkinkan akses yang cepat untuk nutrisi maupun hormon bagi pertumbuhan selnya, serta dapat diproduksi dalam skala besar (Mustafa et al. 2011).

Metode kultur sel telah banyak dikembangkan dengan elisitasi. Elisitasi merupakan suatu teknik dalam sistem kultur in vitro untuk menciptakan kondisi stres (tercekam) melalui perubahan fisiologis atau metabolisme tumbuhan sehingga diharapkan meningkatkan produksi metabolit sekunder. Elisitasi dilakukan dengan menambahkan senyawa yang dinamakan elisitor. Beberapa penelitian telah mencoba menggunakan elisitor untuk meningkatkan produksi kuinina. Penggunaan elisitor berupa asam absisat dan paklobutrazol dengan beragam konsentrasi diketahui dapat meningkatkan produksi kuinina pada kultur sel kina (Ratnadewi \& Sumaryono 2010; Satriawan 2012; Pratiwi 2017). Apabila penggunaan elisitor dapat meningkatkan produksi suatu metabolit sekunder maka aktivitas enzim-enzim pada lintasan biosintesis metabolit sekunder tersebut diduga juga meningkat. Hasil penelitian Ivanov et al. (2013) menyatakan bahwa aktivitas enzim fenilalanina amonia liase yang meningkat diketahui juga meningkatkan biosintesis asam fenolat pada kultur sel Leucojum aestivum (Loddon lily) yang diberi elisitor. Hal ini menimbulkan pertanyaan untuk kuinina, tentang enzim mana pada lintasan biosintesis kuinina yang nyata terelisitasi oleh perlakuan yang diberikan.

Sejauh ini, informasi mengenai enzim yang berperan dalam pembentukan kuinolina, terutama yang paling dekat dengan kuinina, masih sangat terbatas. Isaac et al. (1987) berhasil mengisolasi dan memurnikan enzim NADPH oksidoreduktase dari suspensi sel $C$ ledgeriana. Enzim NADPH oksidoreduktase merupakan salah satu enzim yang berperan dalam jalur biosintesis alkaloid kuinolina, termasuk kuinina. Aktivitas enzim ini, dari kultur sel yang dielisitasi penting untuk diuji, dalam upaya untuk meningkatkan biosintesis alkaloid kuinina. Dengan demikian, potensi rekayasa enzimatis dan genetis dapat dimanfaatkan di kemudian hari.

\section{METODE PENELITIAN}

\section{Bahan Penelitian}

Kalus kina (Cinchona ledgeriana Moens) klon QRC 315, media woody plant (WP), sorbitol, manitol, asam absisat (ABA), paklobutrazol (PBZ), kuinina sulfat, dan $\beta$-Nicotinamide-adenine dinucleotide phosphate $(\beta$ -
$\mathrm{NADP}^{+}$oxidized form monosodium salt). Penelitian dilaksanakan di Laboratorium Kultur Jaringan Tanaman dan Laboratorium Terpadu Departemen Biologi, Laboratorium Bersama Departemen Kimia, dan Laboratorium Spektroskopi Departemen Fisika, FMIPA IPB.

\section{Proliferasi Kalus, Homogenisasi, dan Kultur Suspensi Sel}

Kalus dibiakkan pada media dalam ruangan gelap $\left(25^{\circ} \mathrm{C}\right)$ selama 4 pekan. Kalus lalu dipindahkan ke dalam baffled flask yang berisi media WP cair, yang disebut tahap homogenisasi, dan dipelihara selama 2 pekan. Selanjutnya, suspensi sel hasil homogenisasi disaring menggunakan saringan berukuran pori 1000 $\mu \mathrm{m}$ kemudian dengan ukuran pori $45 \mu \mathrm{m}$. Sebanyak 0,5-0,6 g sel hasil saringan dikultur dalam botol-botol kultur berisi media perlakuan $(30 \mathrm{~mL})$. Media dasar WP cair $(\mathrm{pH} 5,7)$ dengan komposisi $15 \mu \mathrm{M}$ pikloram, $1 \mu \mathrm{M}$ floroglusinol, 0,1 $\mu \mathrm{M}$ 6-benzyl amino purina (BAP), ditambah elisitor. Kultur dikocok di atas shaker dengan kecepatan 90 rpm selama 7 pekan. Kultur dibuat dalam 10 ulangan, dan dipelihara dalam ruang kultur bersuhu $25^{\circ} \mathrm{C}$, di bawah cahaya dengan intensitas $20 \mu \mathrm{mol}$ foton $/ \mathrm{m}^{2} / \mathrm{s}$ selama 12 jam per hari. Susunan perlakuan disajikan pada Tabel 1.

\section{Pengukuran Pertumbuhan Sel dan Pemanenan Sel}

Pengukuran volume sel dilakukan untuk melihat pertumbuhan sel, yang diamati setiap pekan selama 7 pekan dengan metode cell volume after sedimentation (CVS) menurut Blom et al. (1992). Pada pekan ke-7, sel dipanen dengan cara disaring menggunakan saringan berukuran pori $45 \mu \mathrm{m}$. Kemudian ditimbang bobot keringnya. Bobot kering ditimbang setelah pengeringan dalam oven pada suhu $60^{\circ} \mathrm{C}$ selama 3-4 hari, atau sampai bobotnya konstan.

\section{Pengukuran Kadar Kuinina}

Prosedur ekstraksi dan fraksionasi kuinina mengikuti metode Pratiwi (2017). Sebanyak 0,15 g serbuk kering digerus dengan mortar dan ditambah 0,5 $\mathrm{mL}$ bufer fosfat ( $\mathrm{pH} 7$ ), kemudian diinkubasi selama 20 menit. Selanjutnya, ditambahkan bufer fosfat $1 \mathrm{~mL}$ dan disaring menggunakan kertas saring. Tiap perlakuan dibuat 3 ulangan. Filtrat selanjutnya dimasukkan ke dalam kolom kromatografi yang berisi silica ge/ G F254, dan dielusi dengan eluen yang terdiri atas bufer fosfat:asetonitril (7:3). Setiap fraksi dikumpulkan hingga volume $5 \mathrm{~mL}$ sampai fraksi ke 3 , yakni pada saat larutan bening pertama diperoleh. Kemudian,

Tabel 1 Perlakuan elisitor dalam kultur suspensi sel Cinchona ledgeriana

\begin{tabular}{ll}
\hline Kode & \multicolumn{1}{c}{ Perlakuan } \\
\hline $\mathrm{K}$ & Kontrol (tanpa elisitor; Sukrosa $30 \mathrm{~g} / \mathrm{L})$ \\
A3K & ABA $3 \mathrm{mg} / \mathrm{L}$ dan Sukrosa $30 \mathrm{~g} / \mathrm{L}$ \\
A3S & ABA 3 mg/L; Sukrosa $20 \mathrm{~g} / \mathrm{L} ;$ Sorbitol 5,3 g/L \\
P7M & PBZ 7 mg/L; Sukrosa $20 \mathrm{~g} / \mathrm{L} ;$ Manitol 5,3 g/L \\
P7-3M & PBZ 7 mg/L (pada pekan ke-3); Sukrosa $20 \mathrm{~g} / \mathrm{L} ;$ \\
& Manitol 5,3 g/L \\
\hline
\end{tabular}


eluat dari fraksi ke 3 ini dianalisis dengan HPLC. Kuinina sulfat digunakan sebagai standar.

\section{Ekstraksi Enzim NADP(H) Oksidoreduktase}

Enzim diekstraksi mengikuti prosedur Isaac et al. (1987). Media ekstraksi terdiri atas 0,2 M HEPES (pH 7,5), 2 mM Titriplex III, dan 5 mM ditiotreitol. Sebanyak $0,5 \mathrm{~g}$ sel beku yang dipanen dari kultur pekan ke-7, digerus dengan mortar lalu ditambahkan $2 \mathrm{~mL}$ media ekstraksi dan $50 \mu \mathrm{g}$ polivinilpolipirolidon (PVPP). Tiap perlakuan dibuat 4 ulangan. Selanjutnya, sampel dihomogenkan dan dilakukan pemecahan sel menggunakan sonicator probe (10 menit), lalu disentrifugasi pada $16.000 \mathrm{~g}$ (25 menit). Supernatan digunakan sebagai sumber enzim dan diukur aktivitasnya menggunakan fluorometer merk FLUOstar Omega (BMG Labtech, USA).

\section{Uji Aktivitas Enzim NADP(H) Oksidoreduktase}

Aktivitas enzim diuji mengikuti prosedur Isaac et al. (1987) dengan sedikit modifikasi. Substrat kuinina disiapkan dengan inkubasi selama \pm 18 jam sebelum digunakan. Selanjutnya, ekstrak kasar enzim (supernatan) dari ke-5 perlakuan, masing-masing direaksikan dengan $1 \mathrm{mM}$ substrat kuinina, $0,5 \mathrm{mM} \beta$ $\mathrm{NADP}^{+}$, dan bufer fosfat sebagai pelarut. Reaksi yang diharapkan terjadi adalah sebagai berikut:

Kuinidinon + NADPH, $\mathrm{H}^{+} \rightleftharpoons($ kuinina + kuinidina $)+\mathrm{NADP}^{+}$

Reaksi dilakukan pada suhu ruang $25^{\circ} \mathrm{C}$ menggunakan black well plate reader berukuran volume 200 $\mu \mathrm{L}$, dan dibuat duplo. Kurva standar dibuat dari larutan kuinina dan bufer fosfat dengan 5 tingkat konsentrasi. Serapan diukur dengan fluorometer pada panjang gelombang eksitasi $340 \mathrm{~nm}$ dan emisi $458 \mathrm{~nm}$. Aktivitas enzim dihitung dengan rumus:

\begin{tabular}{cc} 
Aktivitas enzim & $\begin{array}{c}\text { Konsentrasi substrat }(\mu \mathrm{m})- \\
\text { Konsentrasi akhir kuinina dalam } \\
\text { sampel }(\mu \mathrm{m})\end{array}$ \\
\cline { 2 - 2 }$/ \mathrm{mg}$ protein $=$ & Kadar protein sampel $(\mathrm{mg})$
\end{tabular}

Kadar protein dari kelima perlakuan ditentukan dengan metode Bradford (1976). Sebanyak $200 \mu \mathrm{L}$ ekstrak kasar enzim ditambahkan ke dalam tabung yang berisi $4 \mathrm{~mL}$ larutan Bradford dan dihomogenkan dengan vorteks. Blanko terdiri atas akuades steril yang ditambah dengan larutan Bradford. Absorbansi larutan kemudian diukur dengan spektrofotometer UV/VIS 7205 merek Jenway pada panjang gelombang $595 \mathrm{~nm}$. Kurva standar Bovine Serum Albumin (BSA) dibuat menjadi 6 konsentrasi dengan mereaksikan standar BSA, larutan Bradford, dan akuades steril. Kadar protein sampel selanjutnya dihitung berdasarkan pengukuran absorbansi larutan dan dikalibrasikan pada kurva standar BSA.

\section{Analisis Data}

Data dianalisis menggunakan Rancangan Acak Lengkap (RAL) dengan satu faktor perlakuan yang terdiri atas 5 perlakuan elisitor. Program yang digu- nakan adalah SPSS versi 20 melalui uji sidik ragam (ANOVA). Perbedaan antarperlakuan dilanjutkan dengan uji jarak berganda Duncan pada tingkat signifikansi $5 \%$. Data aktivitas NADP $(\mathrm{H})$ oksidoreduktase disajikan dalam bentuk rerata \pm standar deviasi.

\section{HASIL DAN PEMBAHASAN}

\section{Pertumbuhan dan Biomassa Sel}

Pertumbuhan sel tertinggi pada pekan ke-7 diukur dari volume sel dan ditemukan pada perlakuan $\mathrm{K}$ (Kontrol/tanpa elisitor), yaitu sebesar 3,94 mL, sedangkan pertumbuhan volume sel terendah ditemukan pada perlakuan P7M (paklobutrazol $7 \mathrm{mg} / \mathrm{L}+$ manitol 5,3 $\mathrm{g} / \mathrm{L}$ ), yaitu sebesar $2,03 \mathrm{~mL}$. Pertambahan volume sel pada perlakuan $\mathrm{K}$ terus meningkat dan tidak terhambat mulai dari pekan pertama hingga pekan ke-7. Hal ini menunjukkan bahwa pemberian elisitor secara nyata berpengaruh menekan pertumbuhan sel.

Gambar 1 dan 2 menampilkan perbandingan pertumbuhan sel $C$. ledgeriana antara kontrol dan perlakuan dengan dua jenis elisitor (ABA dan PBZ) selama 7 pekan. Pemberian elisitor ABA menghasilkan pertumbuhan sel yang lebih baik dibandingkan dengan elisitor PBZ. Hal ini terlihat nyata antara pekan ke-6 dan pekan ke-7 kultur. Rata-rata volume sel dari pekan ke-6 ke pekan ke-7 meningkat sebanyak 4,6\% untuk perlakuan A3S, sedangkan untuk perlakuan A3K meningkat sebanyak $4,19 \%$. Hal itu berbeda pada sel yang diberi perlakuan PBZ. Pada P7M, rata-rata volume sel menurun dari kultur pekan ke- 6 ke pekan ke-7, yaitu sebesar $6,4 \%$, yang diikuti dengan perlakuan $\mathrm{P} 7-3 \mathrm{M}$ yang menurun sebesar $2,13 \%$.

Pertumbuhan sel kina juga tercermin dari bobot kering sel (Tabel 2). Bobot kering sel merupakan akumulasi dari senyawa organik yang disintesis dalam sel tumbuhan. Pemberian elisitor ABA diketahui juga menghasilkan rerata bobot kering sel yang lebih tinggi

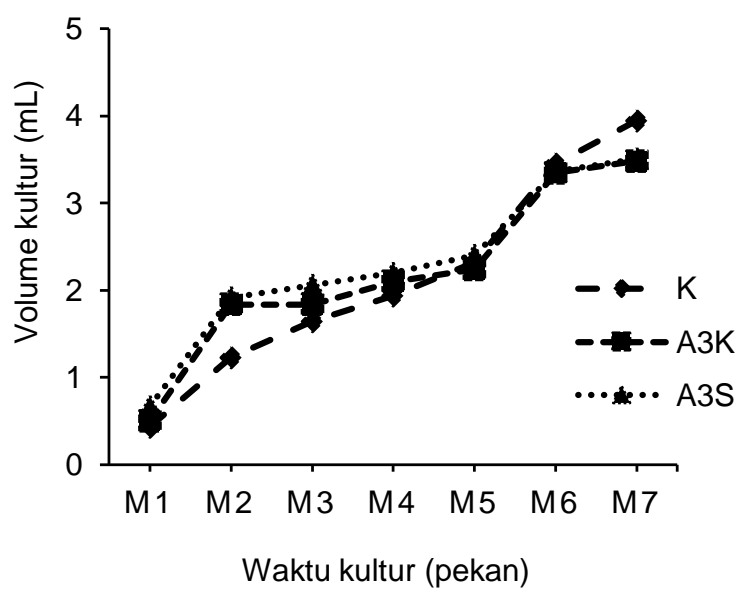

Gambar 1 Pertumbuhan sel kina pada perlakuan ABA. $\mathrm{K}$ (Kontrol, tanpa elisitor) ( $\bullet$ ), A3K (ABA 3 $\mathrm{mg} / \mathrm{L}+$ Sukrosa $30 \mathrm{~g} / \mathrm{L})(\mathbf{m})$, A3S (ABA $3 \mathrm{mg} / \mathrm{L}$ + Sorbitol 5,3 g/L + Sukrosa $20 \mathrm{~g} / \mathrm{L})(\mathbf{\Delta}) . \mathrm{M} 1-$ M7 = Pekan ke-1 hingga ke-7. 


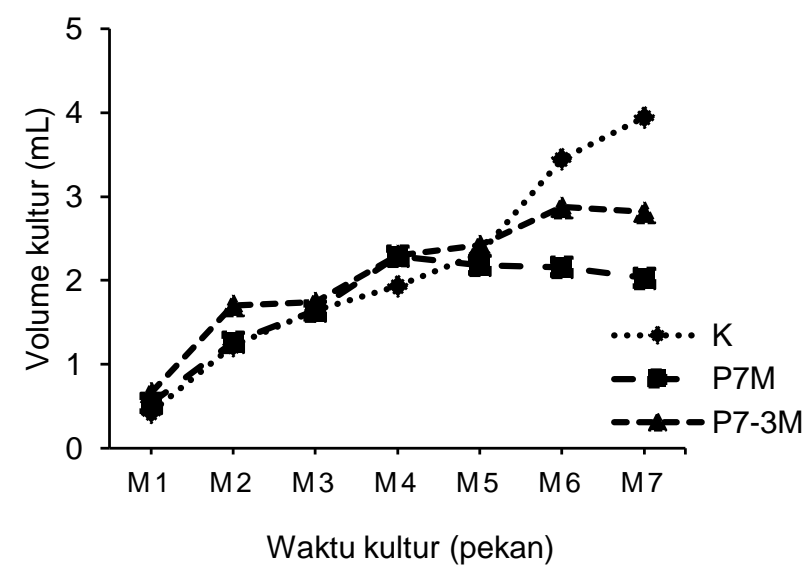

Gambar 2 Pertumbuhan sel kina pada perlakuan PBZ. K (Kontrol, tanpa elisitor) ( $\bullet$ ), P7M (PBZ $7 \mathrm{mg} / \mathrm{L}+$ Manitol 5,3 g/L + Sukrosa $20 \mathrm{~g} / \mathrm{L})(\mathbf{\bullet})$, dan P7-3M (PBZ $7 \mathrm{mg} / \mathrm{L}$ di pekan ke-3 kultur + Manitol 5,3 g/L + Sukrosa $20 \mathrm{~g} / \mathrm{L})(\boldsymbol{\Delta}) \cdot \mathrm{M} 1-\mathrm{M} 7$ = Pekan ke-1 hingga ke-7.

Tabel 2 Rerata bobot kering sel kina umur tujuh pekan

\begin{tabular}{lc}
\hline Perlakuan & Rata-rata bobot kering $(\mathrm{g})$ \\
\hline K & $0,16^{\mathrm{c}}$ \\
A3K & $0,17^{\mathrm{c}}$ \\
A3S & $0,13^{\mathrm{bc}}$ \\
P7M & $0,06^{\mathrm{a}}$ \\
P7-3M & $0,09^{\mathrm{ab}}$ \\
\hline
\end{tabular}

Keterangan: Angka-angka yang diikuti huruf yang sama pada kolom yang sama tidak berbeda nyata berdasarkan uji banding Duncan pada taraf kepercayaan $95 \%$. $\mathrm{K}=$ Kontrol, tanpa elisitor; A3K = ABA 3 mg/L+sukrosa 30 $/ \mathrm{L}$; A3S (ABA $3 \mathrm{mg} / \mathrm{L}+$ sorbitol 5,3 g/L+sukrosa $20 \mathrm{~g} / \mathrm{L} ; \mathrm{P} 7 \mathrm{M}$ = PBZ $7 \mathrm{mg} / \mathrm{L}$ + Manitol 5,3 g/L + Sukrosa 20 $\mathrm{g} / \mathrm{L} ;$ dan $\mathrm{P} 7-3 \mathrm{M}=\mathrm{PBZ} 7 \mathrm{mg} / \mathrm{L}$ di pekan ke-3 kultur + Manitol 5,3 g/L + Sukrosa $20 \mathrm{~g} / \mathrm{L}$.

dibandingkan dengan pemberian PBZ. Rata-rata bobot kering sel tertinggi untuk perlakuan $A B A$ ditemukan pada $A 3 \mathrm{~K}(0,17 \mathrm{~g})$ yang diikuti oleh $\mathrm{A} 3 \mathrm{~S}(0,13 \mathrm{~g})$, yang setara dengan bobot kering sel kontrol. Rata-rata bobot kering sel terendah terdapat pada perlakuan $\mathrm{P} 7 \mathrm{M}(0,06$ g) dan perlakuan P7-3M $(0,09 \mathrm{~g})$. Hasil tersebut mengindikasikan bahwa pemberian elisitor dengan jenis yang berbeda juga menghasilkan respons pertahanan yang berbeda-beda. Pemberian PBZ yang dikombinasikan dengan manitol menyebabkan sel merespons dengan cara menghambat sintesis senyawa organik tertentu atau melalui perubahan kandungan biokimia pada sel tersebut. Penambahan manitol pada larutan nutrisi dapat mempengaruhi karakter morfologi dan fisiologi serta kandungan biokimia pada tumbuhan (Ghaheri et al. 2017), sedangkan penggunaan PBZ dapat menghambat sintesis giberelin (GA) melalui penghambatan enzim biosintesis GA, ent-kaurena oksidase, yang mengatalisis pembentukan entkaurena menjadi asam ent-kaurenat (Kondhare et al. 2014). Secara fisiologis, GA berperan dalam meningkatkan pembentukan organ melalui peningkatan pemanjangan sel dan dalam keadaan tertentu juga meningkatkan pembelahan sel (Hedden \& Thomas 2012). Rahman et al. (2016) melaporkan bahwa pemberian PBZ dapat menyebabkan ukuran sel batang kelapa sawit menjadi lebih kecil dan pendek. Mog et al. (2019) juga menyebutkan bahwa tanaman jambu mete yang diberi PBZ dapat mengalami penurunan parameter pertumbuhan, seperti tinggi tanaman, diameter batang, dan diameter kanopi. Penggunaan elisitor PBZ terbukti mampu menurunkan biomassa total pada sel kina, yang diduga disebabkan oleh penghambatan pada pembentukan senyawa organik primer tertentu dan pembelahan sel sehingga bobot serta ukuran sel menjadi berkurang.

ABA dan PBZ dikenal sebagai zat yang dapat menghambat pertumbuhan tumbuhan. Akan tetapi, $A B A$ juga diketahui dapat melindungi tumbuhan dari kondisi cekaman. Kadar ABA pada tumbuhan meningkat pada saat berada pada kondisi tercekam (stress) melalui induksi gen untuk biosintesis ABA sehingga terjadi perubahan biokimia pada tumbuhan untuk bertahan menghadapi cekaman (Melcher et al. 2010). ABA dan PBZ yang dikombinasikan dengan sukrosa dan gula alkohol manitol atau sorbitol, bertujuan untuk mengubah ketersediaan gula untuk metabolisme. Sukrosa merupakan sumber energi dan karbon utama yang berperan penting dalam metabolisme sel. Pertumbuhan sel yang lebih baik pada penggunaan elisitor ABA dan sorbitol dibandingkan dengan penggunaan PBZ dan manitol menunjukkan bahwa bagian sukrosanya masih dapat dimanfaatkan dengan baik oleh sel sehingga respons stres oleh adanya $A B A$ yang seharusnya terjadi, tidak terlihat nyata. Steinitz (1999) menyatakan bahwa dalam studi in vitro, gula alkohol dapat diasimilasi atau dapat berfungsi sebagai metabolit dan mengubah proses fisiologis melalui pensinyalan kimiawi. Oleh karena itu, sel dengan perlakuan A3S yang tumbuh dengan baik seperti A3K, diduga karena sorbitol dapat dimanfaatkan dalam metabolisme sel, yang berfungsi dalam regulasi pertumbuhan.

\section{Kadar Kuinina}

Analisis kadar kuinina pada kultur sel kina berumur 7 pekan menunjukkan hasil yang nyata berbeda menurut perlakuannya. Rerata kadar kuinina tertinggi dalam sel ditemukan pada perlakuan P7M $(100,95$ $\mu \mathrm{g} / \mathrm{g})$ yang diikuti oleh perlakuan A3S $(23,12 \mu \mathrm{g} / \mathrm{g})$, seperti yang tersaji pada Tabel 3 . Rerata kadar kuinina terendah ditemukan pada perlakuan A3K $(12,54 \mu \mathrm{g} / \mathrm{g})$, yang kemudian meningkat pada $\mathrm{K}(13,32 \mu \mathrm{g} / \mathrm{g})$ dan P73M $(14,21 \mu \mathrm{g} / \mathrm{g})$. Hasil ini mengindikasikan bahwa elisitor berpengaruh dalam meningkatkan produksi kuinina. Kadar alkaloid diketahui meningkat setelah kultur dielisitasi menggunakan elisitor tertentu, di antaranya hidrogen peroksida untuk produksi alkaloid $\beta$-karbolina pada kultur akar rambut Peganum harmala (Syrian rue)(Zayed 2011), metil jasmonat untuk produksi alkaloid kamptotekin dari kultur tunas Ophiorrhiza mungos (dathketiya) (Krishnan et al. 
2018), dan paklobutrazol untuk produksi kuinina pada kultur sel C. ledgeriana (kina) (Ratnadewi et al. 2013).

Semakin tinggi kondisi cekaman pada kultur, umumnya semakin tinggi pula kandungan metabolit sekundernya. Oleh sebab itu, produksi kuinina tertinggi yang dihasilkan oleh perlakuan P7M yang sebanding dengan cekaman (stress) yang dialaminya. Hal ini terlihat dari rendahnya pertumbuhan sel dan biomassa yang dihasilkan. Pembentukan produk metabolisme primer untuk pertumbuhan sel diduga dialihkan menjadi biosintesis metabolit sekunder, sedangkan pada perlakuan kontrol, biosintesis metabolit sekunder sedikit karena pertumbuhan secara normal diarahkan untuk menghasilkan produk metabolit primer (Bourgaud et al. 2001).

\section{Aktivitas NADP(H) Oksidoreduktase}

Proses enzimatis yang terjadi pada penelitian ini merupakan reaksi reversibel. Kuinina digunakan sebagai substrat yang akan teroksidasi dengan bantuan oksidoreduktase dan $\mathrm{NADP}^{+}$sebagai koenzim, kemudian menghasilkan produk kuinidinon. Atau kuinidinon tereduksi membentuk kuinina melalui katalisis $\operatorname{NADP}(\mathrm{H})$ oksidoreduktase. Hal ini menjelaskan bahwa kuinina dapat dijadikan sebagai substrat dan dikonversi menjadi produk, yakni kuinidinon. Menurut Isaac et al. (1987), terdapat dua isoenzim

Tabel 3 Kadar kuinina sel Cinchona ledgeriana pada pekan ke-7 kultur

\begin{tabular}{lc}
\hline Perlakuan & Kadar kuinina dalam suspensi sel $(\mu \mathrm{g} / \mathrm{g})$ \\
\hline K & $13,32^{\mathrm{ab}}$ \\
A3K & $12,54^{\mathrm{a}}$ \\
A3S & $23,12^{\mathrm{b}}$ \\
P7M & $100,95^{\mathrm{c}}$ \\
P7-3M & $14,21^{\mathrm{ab}}$
\end{tabular}

Keterangan: Angka-angka yang diikuti huruf yang sama pada kolom yang sama tidak berbeda nyata berdasarkan uji banding Duncan pada taraf kepercayaan $95 \%$. $\mathrm{K}=$ Kontrol, tanpa elisitor; A3K = ABA $3 \mathrm{mg} / \mathrm{L}+$ sukrosa $30 \mathrm{~g} / \mathrm{L}$; A3S (ABA $3 \mathrm{mg} / \mathrm{L}+$ sorbitol $5,3 \mathrm{~g} / \mathrm{L}+$ sukrosa $20 \mathrm{~g} / \mathrm{L} ; \mathrm{P} 7 \mathrm{M}$ = PBZ $7 \mathrm{mg} / \mathrm{L}+$ Manitol 5,3 g/L + Sukrosa 20 $\mathrm{g} / \mathrm{L}$; dan P7-3M = PBZ $7 \mathrm{mg} / \mathrm{L}$ di pekan ke-3 kultur + Manitol 5,3 g/L + Sukrosa $20 \mathrm{~g} / \mathrm{L}$. untuk $\operatorname{NADP}(\mathrm{H})$ oksidoreduktase. Isoenzim I hanya bekerja pada substrat sinkoninon, sedangkan isoenzim II diketahui memiliki spesifisitas substrat yang lebih luas karena dapat bekerja pada substrat sinkoninon dan kuinidinon. Isaac et al. (1987) dalam penelitiannya pada suspensi sel $C$. ledgeriana itu juga mendapatkan bahwa $\operatorname{NADP}(\mathrm{H})$ oksidoreduktase isoenzim I tidak terdeteksi bekerja pada substrat kuinidinon, kuinidina, atau kuinina. Berdasarkan hal tersebut, $\operatorname{NADP}(\mathrm{H})$ oksidoreduktase Isoenzim II dapat dipastikan yang berfungsi pada ekstrak kasar protein enzim untuk hasil pengujian yang dilakukan karena dapat bekerja pada substrat kuinina.

Berdasarkan rerata hasil, nilai aktivitas enzim tertinggi terdapat pada perlakuan P7M $(165,42 \mu \mathrm{M} / \mathrm{mg}$ protein), yang diikuti oleh perlakuan A3S (156,37 $\mu \mathrm{M} / \mathrm{mg}$ protein) dan A3K (153,27 $\mu \mathrm{M} / \mathrm{mg}$ protein), sedangkan aktivitas enzim terendah dihasilkan oleh sel $\mathrm{K}(143,13 \mu \mathrm{M} / \mathrm{mg}$ protein) seperti yang tersaji pada Gambar 3. Hasil ini menunjukkan bahwa pemberian elisitor ABA dan PBZ yang dikombinasikan dengan sukrosa dan sorbitol/manitol berpengaruh dalam meningkatkan aktivitas $\operatorname{NADP}(\mathrm{H})$ oksidoreduktase. Peningkatan aktivitas enzim tertinggi ditemukan pada sel yang dielisitasi dengan PBZ (P7M) dan ABA (A3S), yaitu berturut-turut sebesar 13,5 dan $8,5 \%$, dibandingkan dengan kontrol (Tabel 4). Isaac et al. (1987) dengan substrat kuinidinon pada $\mathrm{pH} 7$, mendapatkan aktivitas enzim ini sekitar 600 pKat/mg protein. Pada spesies yang sama, enzim lain yang telah diteliti hanya aktivitas enzim striktosidin sintase, yaitu oleh Aerts et al. (1991).

Menurut Ibrahim \& Jaafar (2013), pemberian ABA pada Orthosiphon stamineus (kumis kucing) dapat menginduksi stres oksidatif, yang mengakibatkan peningkatan aktivitas askorbat peroksidase (APX), superoksida dismutase (SOD), dan katalase (CAT), yang diikuti dengan peningkatan senyawa flavonoid. Abbasi et al. (2015) juga menyebutkan bahwa aplikasi PBZ dapat meningkatkan aktivitas APX pada gandum yang diberi cekaman kekeringan. Sel-sel tumbuhan umumnya akan memberikan respons pertahanan dirinya ketika berada pada kondisi tercekam, termasuk

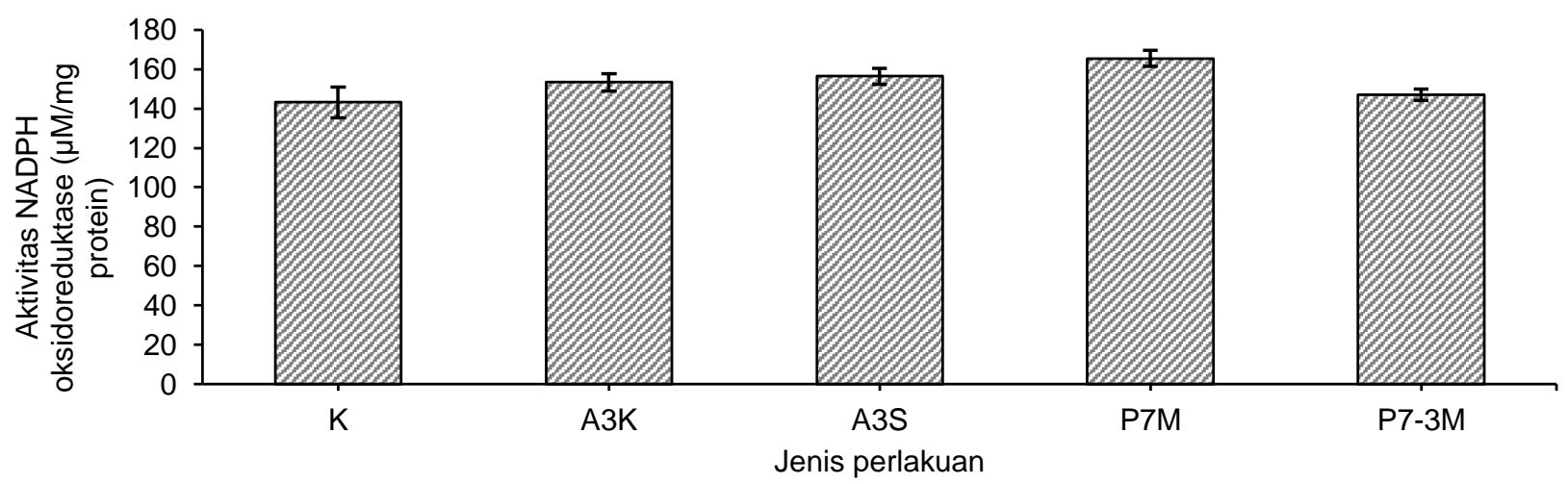

Gambar 3 Rerata aktivitas NADP(H)-oksidoreduktase dengan substrat kuinina. $K=$ Kontrol, tanpa elisitor; $A 3 K=A B A 3$ $\mathrm{mg} / \mathrm{L}+$ sukrosa 30g/L; A3S (ABA $3 \mathrm{mg} / \mathrm{L}+$ sorbitol 5,3 g/L+sukrosa $20 \mathrm{~g} / \mathrm{L} ; \mathrm{P} 7 \mathrm{M}=\mathrm{PBZ} 7 \mathrm{mg} / \mathrm{L}+$ Manitol 5,3 g/L + Sukrosa $20 \mathrm{~g} / \mathrm{L}$; dan P7-3M = PBZ $7 \mathrm{mg} / \mathrm{L}$ di pekan ke-3 kultur + Manitol 5,3 g/L + Sukrosa $20 \mathrm{~g} / \mathrm{L}$. 
Tabel 4 Persentase peningkatan aktivitas NADP $(H)$ oksidoreduktase dari kultur sel kina yang dielisitasi dibandingkan dengan kontrol

\begin{tabular}{|c|c|}
\hline Perlakuan & Peningkatan aktivitas enzim (\%) \\
\hline $\mathrm{K}$ & 0,0 \\
\hline A3K & 6,6 \\
\hline A3S & 8,5 \\
\hline P7M & 13,5 \\
\hline P7-3M & 2,7 \\
\hline $\begin{array}{r}\text { Keterangan: } \\
\mathrm{K} \\
\mathrm{m} \\
\mathrm{m} \\
\mathrm{P} \\
\mathrm{dc} \\
+\end{array}$ & $\begin{array}{l}\mathrm{K}=\text { Kontrol, tanpa elisitor; A3K = ABA } 3 \\
\mathrm{mg} / \mathrm{L}+\text { sukrosa } 30 \mathrm{~g} / \mathrm{L} ; \quad \text { A3S } \quad \text { ABA } 3 \\
\mathrm{mg} / \mathrm{L}+\text { Sorbitol } 5,3 \mathrm{~g} / \mathrm{L}+\text { Sukrosa } 20 \mathrm{~g} / \mathrm{L} ; \mathrm{P} 7 \mathrm{M}= \\
\mathrm{PBZ} 7 \mathrm{mg} / \mathrm{L}+\text { Manitol } 5,3 \mathrm{~g} / \mathrm{L}+\text { Sukrosa } 20 \mathrm{~g} / \mathrm{L} ; \\
\text { dan P7-3M = PBZ } 7 \mathrm{mg} / \mathrm{L} \text { di pekan ke-3 kultur } \\
\text { + Manitol } 5,3 \mathrm{~g} / \mathrm{L}+\text { Sukrosa } 20 \mathrm{~g} / \mathrm{L} \text {. }\end{array}$ \\
\hline
\end{tabular}

ketika dielisitasi. Respons pertahanan tersebut dapat berupa respons fisiologis dan respons molekuler, yang dapat terdeteksi antara lain dengan peningkatan biosintesis metabolit sekunder tertentu.

Pemberian elisitor menyebabkan perubahan metabolisme tumbuhan dan memungkinkan pengaktifan gen-gen spesifik. Pan et al. (2018) menyatakan bahwa elisitasi dengan asam jasmonat pada Cataranthus roseus dapat meningkatkan ekspresi gen-gen penyandi enzim-enzim biosintesis alkaloid indol terpenoid (TIA), seperti STR, SGD, DAT, dan PRX1. Wang et al. (2015) juga melaporkan bahwa pemberian elisitor metil jasmonat dapat meningkatkan biosintesis flavonoid melalui peningkatan aktivitas fenilalanina amonia liase (PAL). Hal ini diduga juga berlaku pada tanaman kina melalui pemberian elisitor PBZ/ABA yang menginduksi aktivitas $\operatorname{NADP}(\mathrm{H})$ oksidoreduktase, yang diikuti oleh peningkatan akumulasi senyawa kuinina, meskipun mekanismenya secara terperinci belum sepenuhnya diketahui. Peningkatan aktivitas $\operatorname{NADP}(\mathrm{H})$ oksidoreduktase dari kultur sel yang dielisitasi (P7M dan A3S), sejalan dengan peningkatan produksi/akumulasi kuinina.

Dalam kondisi normal, NADP $(\mathrm{H})$ oksidoreduktase diproduksi oleh sel kina dan aktif dalam mensintesis kuinolina. Hal ini terlihat dari deteksi dan aktivitas enzim yang dihasilkan dari kultur sel yang tidak dielisitasi (kontrol). Akan tetapi, aktivitas enzim yang terdapat pada kontrol tersebut sangat rendah. Hasil percobaan menunjukkan bahwa aktivitas enzim $\operatorname{NADP}(\mathrm{H})$ oksidoreduktase meningkat dengan penambahan elisitor (Tabel 4). Hal ini juga sejalan dengan peningkatan sintesis kuinolina, yang ditunjukkan dengan kecenderungan peningkatan kadar kuinina pada sel yang dielisitasi.

\section{KESIMPULAN}

Aktivitas enzim biosintesis alkaloid kuinolina, yakni $\operatorname{NADP}(\mathrm{H})$ oksidoreduktase, terdeteksi pada sel kontrol dan semua perlakuan elisitor, namun kultur sel yang dielisitasi menghasilkan aktivitas enzim yang lebih tinggi dibandingkan dengan yang tidak dielisitasi.
Penggunaan elisit or berupa paklobutrazol yang diberikan di awal kultur dan manitol (P7M) yang diikuti dengan asam absisat dan sorbitol (A3S) menghasilkan alkaloid kuinina tertinggi yang sesuai dengan pola aktivitas $\operatorname{NADP}(\mathrm{H})$ oksidoreduktase yang tinggi. Peningkatan aktivitas enzim pada sel yang dielisitasi menunjukkan bahwa biosintesis kuinolina, khususnya kuinina, dapat ditingkatkan melalui manipulasi enzim, khususnya $\operatorname{NADP}(\mathrm{H})$ oksidoreduktase, dengan substrat yang tepat.

\section{UCAPAN TERIMA KASIH}

Terima kasih kepada Direktorat Riset dan Pengabdian Masyarakat, Direktorat Jenderal Penguatan Riset dan Pengembangan, Kementerian Riset Teknologi dan Pendidikan Tinggi, yang telah membiayai penelitian ini melalui skema PTUPT Tahun Anggaran 2018.

\section{DAFTAR PUSTAKA}

Abbasi A, Shekari F, Mustafavi SH. 2015. Effect of paclobutrazol and salicylic acid on antioxidants enzyme activity in drought stress in wheat. Idesia. 33(4): 5-13.

Aerts RJ, de Waal A, Pennings EJ, Verpoorte R. 1991. The distribution of strictosidine-synthase activity and alkaloids in Cinchona plants. Planta. 183(4): 536-541.

Awasthi S, Srivastava A, Singla ML. 2011. Voltammetric determination of citric acid and quinine hydrochloride using polypyrrolepentacyanonitrosylferrate/platinum electrode. Synthetic Metals. 161: 1707-1712. https://doi.org/ 10.1016/j.synthmet.2011.06.009.

Blom TJM, Kreis W, Van Iren F, Libbenga KR. 1992. A non-invasive method for the routine-estimation of fresh weight in batch suspension cultures. Plant Cell Reports. 11: 146-149.

Bourgaud F, Gravot A, Milesi S, Gontier E. 2001. Review: production of plant secondary metabolites: a historical perspective. Plant Science. 161(5): 839851.

Bradford MM. 1976. A rapid and sensitive method for the quantitation of microgram quantities of protein utilizing the principle of protein-dye binding. Analytical Biochemistry. 72: 248-254. https://doi: 10.1006/abio.1976.9999.

De Pablos-Martinez C, Porte L, Fraissinet F, Berry A, Séraissol $P$, Lavit $M$, Chatelut $E$, Concordet $D$, Gandia P. 2016. Quinine unbound concentration is the bestmarker for therapeutic drug monitoring. 
Therapie. 71(5): 487-489. https://doi.org/10.1016/ j.therap.2016.02.032.

Flieger J, Zelazko AC. 2015. Aqueous two phase system based on ionic liquid for isolation of quinine from human plasma sample. Food Chemistry. 166: 150-157. https://doi.org/10.1016/j.foodchem.2014. 06.037.

Ghaheri M, Kahrizi D, Bahrami G. 2017. Effect of mannitol on some morphological characteristics of in vitro Stevia rebaudiana Bertoni. Biharean Biologist. 11(2): 94-97.

Hedden P, Thomas SG. 2012. Gibberellin biosynthesis and its regulation: Review. Journal of Biochemistry. 444: 11-25. https://doi.org/10.1042/BJ20120245.

Ibrahim MH, Jaafar HZE. 2013. Abscisic acid induced changes in production of primary and secondary metabolites, photosynthetic capacity, antioxidant capability, antioxidant enzymes and lipoxygenase inhibitory activity of Orthosiphon stamineus Benth. Molecules. 18: 7957-7976. https://doi.org/10.3390/ molecules 18077957.

Isaac JE, Robins RJ, Rhodes MJC. 1987. Cinchonine: NADPH oxidoreductase I and II-novel enzymes in the biosynthesis of quinoline alkaloids in Cinchona ledgeriana. Phytochemistry. 26(2): 393-399. https://doi.org/10.1016/S0031-9422(00)81420-X.

Ivanov I, Georgiev V, Pavlov A. 2013. Elicitation of galanthamine biosynthesis by Leucojum aestivum liquid shoot cultures. Journal of Plant Physiology. 170: 1122-1129. https://doi.org/10.1016/j.jplph. 2013.03.017.

Kondhare KR, Hedden $P$, Kettlewell PS, Farrell $A D$, Monaghan JM. 2014. Use of the hormonebiosynthesis inhibitors fluridone and paclobutrazol to determine the effects of altered abscisic acid and gibberellin levels on pre-maturity a-amylase formation in wheat grains. Journal of Cereal Science. 60(1): 210-216. https://doi.org/10.1016/ j.jcs.2014.03.001.

Krishnan JJ, Gangaprasad A, Satheeshkumar K. 2018. Exogenous methyl jasmonate acts as a signal transducer in the enhancement of camptothecin (CPT) production from in vitro cultures of Ophiorrhiza mungos L. var. angustifolia (Thw.) Hook. F. Industrial Crops and Products. 119: 93101. https://doi.org/10.1016/j.indcrop.2018.04.007.

Krishnaveni M, Suresh K, Rajasekar M. 2015. Antioxidant and free radical scavenging activity of quinine determined by using different in vitro models. International Journal of Modern Research and Reviews. 3: 569-574.

Melcher K, Zhou XE, Xu HE. 2010. Thirsty plants and beyond: structural mechanisms of abscisic acid perception and signaling. Current Opinion in
Structural Biology. 20(6): 722-729. https://doi.org/ 10.1016/j.sbi.2010.09.007.

Mog B, Janani P, Nayak MG, Adiga JD, Meena R. 2019. Manipulation of vegetative growth and improvement of yield potential of chasew (Anacardium occidentale L.) by paclobutrazol. Scientia Horticulturae. 257(17): 108748 https:// doi.org/10.1016/ j.scienta.2019.108748.

Mustafa NR, de Winter W, van Iren F, Verpoorte R. 2011. Initiation, growth and cryopreservation of plant cell suspension cultures. Natural Protocols. 6: 715-742. https://doi.org/10.1038/nprot.2010.144.

Pan Q, Saiman MZ, Verpoorte R, Tang K. 2018. Accumulation of terpenoid indole alkaloids in jasmonic acid elicited Catharanthus roseus plants before and during flowering. Pakistan Journal of Botany. 50(3): 1077-1083.

Pratiwi DR. 2017. Senyawa sekunder dalam jaringan dan suspensi sel kina (Cinchona ledgeriana Moens): analisis anatomi, histokimia, dan kadarnya. [Tesis]. Bogor (ID): Institut Pertanian Bogor.

Rahman MNHA, Shaharuddin NA, Wahab NA, Wahab PEM, Abdullah MO, Abdullah NAP, Parveez GKA, Roberts JA, Ramli Z. 2016. Impact of paclobutrazol on the growth and development of nursery grown clonal oil palm (Elaeis guineensis Jacq.). Journal of Oil Palm Research. 28(4): 404-414.

Ratnadewi D, Satriawan D, Sumaryono. 2013. Enhanced production level of quinine in cell suspension culture of Cinchona ledgeriana Moens by paclobutrazol. Biotropia. 20(1): 10-18. http:// dx.doi.org/10.11598/btb.2013.20.1.291 .

Ratnadewi D, Sumaryono. 2010. Quinoline alkaloids in suspension cultures of Cinchona ledgeriana treated with various substances. HAYATI Journal of Biosciences. 17(4): 179-182. https://doi.org/ 10.4308/hjb.17.4.179.

Satriawan D. 2012. Peningkatan kandungan alkaloid kinin dalam suspensi sel kina (Cinchona ledgeriana Moens) dengan perlakuan senyawa kimia. [Tesis]. Bogor (ID): Institut Pertanian Bogor.

Steinitz B. 1999. Sugar alcohols display nonosmotic roles in regulating morphogenesis and metabolisms in plants that do not produce polyols as primary photosynthetic products: review. Journal of Plant Physiology. 155: 1-8.

Wang J, Qian J, Yao L, Lu Y. 2015. Enhanced production of flavonoids by methyl jasmonate elicitation in cell suspension culture of Hypericum perforatum. Bioresources and Bioprocessing. 2(5): 1-9. https://doi.org/10.1186/s40643-014-0033-5.

Zayed R. 2011. Efficient in vitro elicitation of $\beta$ carboline alkaloids in transformed root cultures of Peganum harmala. Bulletin of Faculty of Pharmacy, Cairo University. 49(1): 7-11. 